\title{
Research on Business Model of Rural online Group-buying on Contacts
}

\author{
Jian-chi Xiang ${ }^{a,}$ Wu-yong Ding ${ }^{b}$ \\ School of Business, Hunan normal university, Changsha, China \\ ajcxiang@sina.com, bwadwy0330@live.cn
}

Keywords: online group-buying; business model; rural; SWOT

\begin{abstract}
According to the trend of Internet development, this paper first analyzes the feasibility of online group-buying activities based on the characteristics of the rural market and online group-buying. Then it presents a rural online group-buying model based on the contacts. Finally, it analyses this mode based on the SWOT approach. Generally speaking, this paper provides an inspiration and reference for the development of the group-buying online industry, by the exploring study on the online group-buying of the rural areas.
\end{abstract}

\section{Introduction}

According to the statistical data presented in the $29^{\text {th }}$ report of china Internet network development, which is issued by China Internet Network Information Center (CNNIC) in 2012, the number of Chinese internet users has reached 513,000,000 and the Internet penetration rate has come up to $38.3 \%$. Besides that the number of the online purchasers has reached 194,000,000 which have improved by $20.8 \%$ compared with the same results in 2010 . Since trading volume of the online group-buying grows rapidly, the annual growth rate of the number of the users goes up to $244.8 \%$ and user scale reaches 64.65 million. The utilization ratio of the group-buying raise to $12.6 \%{ }^{[1]}$. Hence, online group-buying becomes a new kind of e-business models. In 2003, Anand and Aron had put forward a perspective, namely "group buying on the web", which can gather the same requirements of different consumers via internet. Then the consumers' advantages can be obtained by the bulk buying scheme. This scheme can also improve the bargaining power and create a good buying condition. Its goal is to reduce transaction costs and risk and increase the consumption-utility of the consumer groups ${ }^{[2]}$. Since the first group-buying website "groupon" established in 2008 and appeared on the market in 2011, Online group-buying begins to sweep across the world quickly by its unique competitive advantage and huge market demand. In terms of the census data presented in the bulletin of national group-buying website in 2011, which is announced by the Chinese authoritative group-buying data center "Leading Group Buying", 5877 online group-buying websites in our country has been created by the end of 2011. Moreover, the total trading value of the online group-buying reached as high as RMB 21,632,000,000 in 2011 which has a sharp growth rate by $765 \%$ compared with 2.5 billion in $2010^{[3]}$.

However, the research on the online group-buying is still in its early stages. Although scholars at home and abroad have done some related researches, the results are fragmentary and lack of system. Besides that, the theoretical researches of the online group-buying do not meet the social need for the online group-buying and the online group-buying practice of the enterprises. In a word, the related practice locations almost focus on cites, especially on the big-middle cities, while the rural market are taken little attention. It means that no matter it is a theoretical research or an enterprises practice, the related information of the online group-buying based on the rural market is few. According to the statistical data presented in $6^{\text {th }}$ bulletin of 2010 national population census, which is published by the State Statistics Bureau, among the population of 31 mainland provinces, autonomous regions, municipalities and servicemen, the number of people who live in cities and towns is 665.6 million which occupies for $49.68 \%$ of the total. While the number of people who lives in the rural areas are 674, 1 million which occupies for $50.32 \%{ }^{[4]}$. In 2011 , the number of rural netizens reaches 136 million which increases by 11.13 million compared with the results of 2010 years and accounts for $26.5 \%$ of the whole internet users. Facing with such a huge rural markets and an increasing rural netizens team, it is urgent and meaningful to do some prospective study about the online group-buying based on rural market. 


\section{Feasibility analysis on rural online group buying}

Currently, online group-buying as a kind of new e-commerce models has three main participations: merchants, consumers and website. The feature of the "tripartite win-win situation" is obvious, which is the basic reason why the online group-buying can develop rapidly. From the merchants' view, because the group-buying can provide much lower discounts on goods and much better quality on the service than that of the traditional mode, the costs are reduced, the profits are improved and the intermediate sales channels are ignored by the mass productions and sales. For the consumers, compared with traditional shopping pattern, they can purchase the goods with a higher cost performance, convenient services and saving-time operations. Besides that, they could have a perfect consumer experience. To website, it provides the network trade platform and obtains the corresponding commission at a lower cost. Moreover, it creates opportunities for putting the advertisements so as to realize the enterprise development.

The above models can also be called the group-buying model based on city. And its unique advantage is the main reason why thousands of group-buying sites devote themselves to work on the urban market currently. According to the above descriptions, the conditions of the online group-buying in the rural market are not mature. From the businessman's view, the traffic facilities are imperfect and the residences are dispersal which will lead to a higher transporting cost. On the side of the rural consumers, the penetrating power of the computer is low in rural areas and the infrastructure of the internet is imperfect. The related operations about how to get online group-buying information or pay on the internet all need farmers to have an internet operating ability. However, most farmers are lack of this ability. The imperfect internet infrastructure and immature network operations make the potential demand can not be expressed and the high logistics costs which result in the actual demand can not be implemented. These factors hinder the current online group-buying model being introduced in rural areas.

With the penetrating power of the internet increasing, the construction of China's new countryside develops with a accelerate speed. And the information qualities of farmers are enhanced day by day. Especially, the project that the college graduates work as heads in the village will create the more conditions for rural group buying.

Improve rural transport and network facilities. With the government's attention to the problem of "Agriculture, Rural areas and Peasantry" and increasing financial investment, the infrastructure of the rural transportation is improved greatly. According to statistical data presented in the report of Highway and waterway transport sector's development (part of rural roads), which is issued by the ministry of transport in 2011 , more than $99.97 \%$ of township (town) in china are now accessible by highway, and $99.38 \%$ of administrative villages are accessible by road ${ }^{[5]}$. The improvement of rural traffic facilities makes the rural logistics of the network group-buying become possible.

In recent years, we have made a great progress in setting up the rural network. By carrying out some projects such as "rural-to-rural traffic available" and "broadband access to villages", the infrastructures of the rural areas can be built quickly, which provide a good foundation for the development of agricultural informationization. By the end of 2010, 100\% of the towns are connected to internet, and $89 \%$ of them are accessed to the broadband internet. And 30,000 agricultural websites, 20,200 town information service stations and 117,300 rustic information service stations have been established ${ }^{[6]}$.

Enhance Farmers' awareness of using Network. With the development of rural informatization, farmers' awareness of information is enhanced constantly and the power of their consumption capabilities is growing. Besides that, by carrying out a series of national policies, e.g. "computer goes to the countryside", "broadband goes to the countryside" and "college students serve as village leads", the requirements for the information services in rural areas become more and more urgent. The Village committees can be accessed to by the broadband internet, and the village cadres take the information training periodically by the guide of the village committee. Recently, a hundred thousand of graduates who serve as village leads bring external information resources to the rural areas. And the fact that rural youths return home also brings the demand and the usage capacity of network. 
More requirements of online group-buying in rural areas than in urban areas. Since there are some disadvantages of the rural areas, for instance, geographical disadvantages, information asymmetry, the redundant agent link, small optional range and higher logistics cost, farmers usually pay much more money for the goods than that in countryside. However, the online group-buying can eliminate the problems like regional disadvantage and information asymmetry easily by the internet. Concentrated purchase and delivery shorten the logistics costs and make the distinct advantage of online group-buying be expressed in countryside.

Homogeneity of rural consumption. In the traditional rural market, the villagers usually have a higher social trust than citizens. So there is a significant impact of the reputation and herd behavior on the purchasing behavior of the rural consumers ${ }^{[7]}$. This feature not only gives the suitable soil for the online group-buying to survival in rural market, but also makes the merchants and group-buying websites to build a good reputation. From the perspective of the rural consumer goods, the demands of rural market usually have the localized features. The consumers in the same area have the same demand of life goods and agricultural materials. Compared with the personalized urban consumption, rural consumption has a homogeneous feature which may cater to the trait of the product of online group-buying.

\section{Analysis the model of online group-buying based on contacts}

Build the model of rural online group-buying. In order to make the rural online group-buying be feasible, it is necessary to modify the urban online group-buying model in accordance with the characteristics of rural market. There are three subjects in the original model: consumer, merchant and online group-buying web. Among these subjects, the main consumers in the rural areas, namely "peasant", are the greatest obstacle which blocks the promotion of the online group-buying in countryside. The main reason is that the peasants are lack of information foundation which includes internet access conditions and the internet operational ability. These disadvantages result in the potential demand of the farmers can not be expressed well.

The way to solve this problem is to set a new subject to connect the farmers and merchant. This subject replaces the functions of the rural consumers with expressing their demands and operating the network. Therefore, there are four subjects in the rural online group-buying model: consumers, contacts, merchants and websites. It is different from the original model which is shown in Fig.1

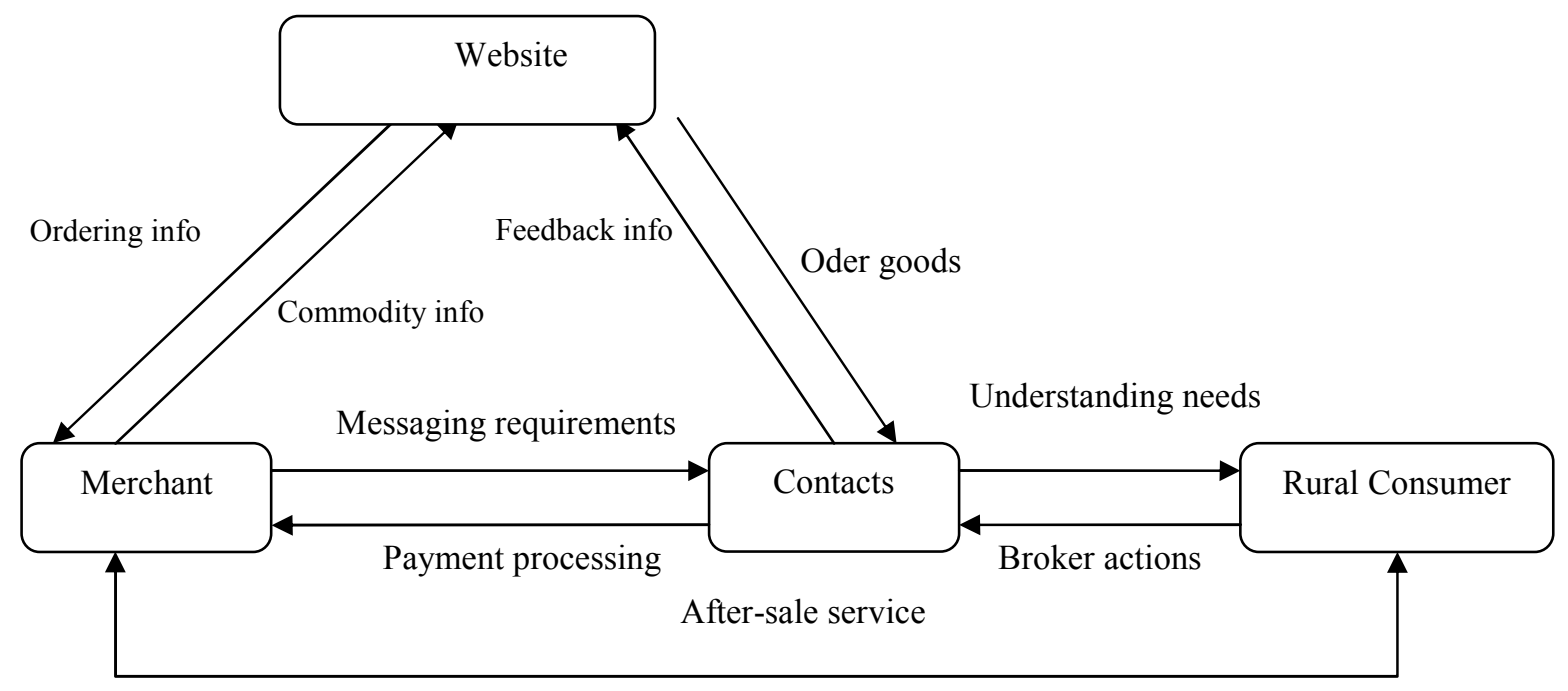

Delivering commodity

Fig.1: The online group-buying business model based on rural area

By adding a 'contact' as the subject, the consumers "farmer" do not need to trade with website and merchant directly. They do transaction through contacts. These schemes make up for the imperfect rural network infrastructure and inadequate internet operational capacity. Hence, it is 
feasible to promote the online group-buying activities in countryside. Contacts can be the clients of villages in a region (one or a few villages) who has the principal-client relationship with villagers. Generally speaking, the contacts are the ones who have the ability to use internet such as village cadres or college-graduates in countryside. And the primary work is to collect the demands of the villagers and communicate with websites and merchants on the behalf of farmers.

Analysis on the process of rural online group-buying based on contacts. At first, farmer should report their demands to local contacts and complete the subsequent work according to the notice of the contacts. The contacts should register on the website by their real-name in the name of local area. During the purchase process, he should collect the demands of farmers and release the results on the website, and then wait for the business bid. If some enterprises win the bid, contacts need to raise payment from the farmers according to the price provided by the enterprises, then pay the certain margins to online group-buying organization and wait for the merchants' delivery. Contacts have an obligation to check the quality of the goods once the goods are received. If there are some problems with the quality, contacts should solve this problem by a corporate negotiation with merchant. Contacts can also return the goods to the merchant. If everything is ok, contacts should pay the remaining money to the merchant and evaluate the related service on the web.

Online group-buying websites need to invite local contacts and enterprises to do real-name registration on the site. Once the transaction is finished, the site should remove the commission and pay the remaining money to the merchant. If there are some problems with quality during the usage process, website should help contacts to safeguard their rights. The merchant should register on the online group-buying website with their real name, then search the information of supply and demand on the website and set a suitable quota for it. If a merchant win the bid, he needs to deliver the products to the contacts. If the goods are qualified, the merchant should obtain the remaining money which has been removed the commission of website. The process of the rural online group-buying based on contacts is shown as Fig.2

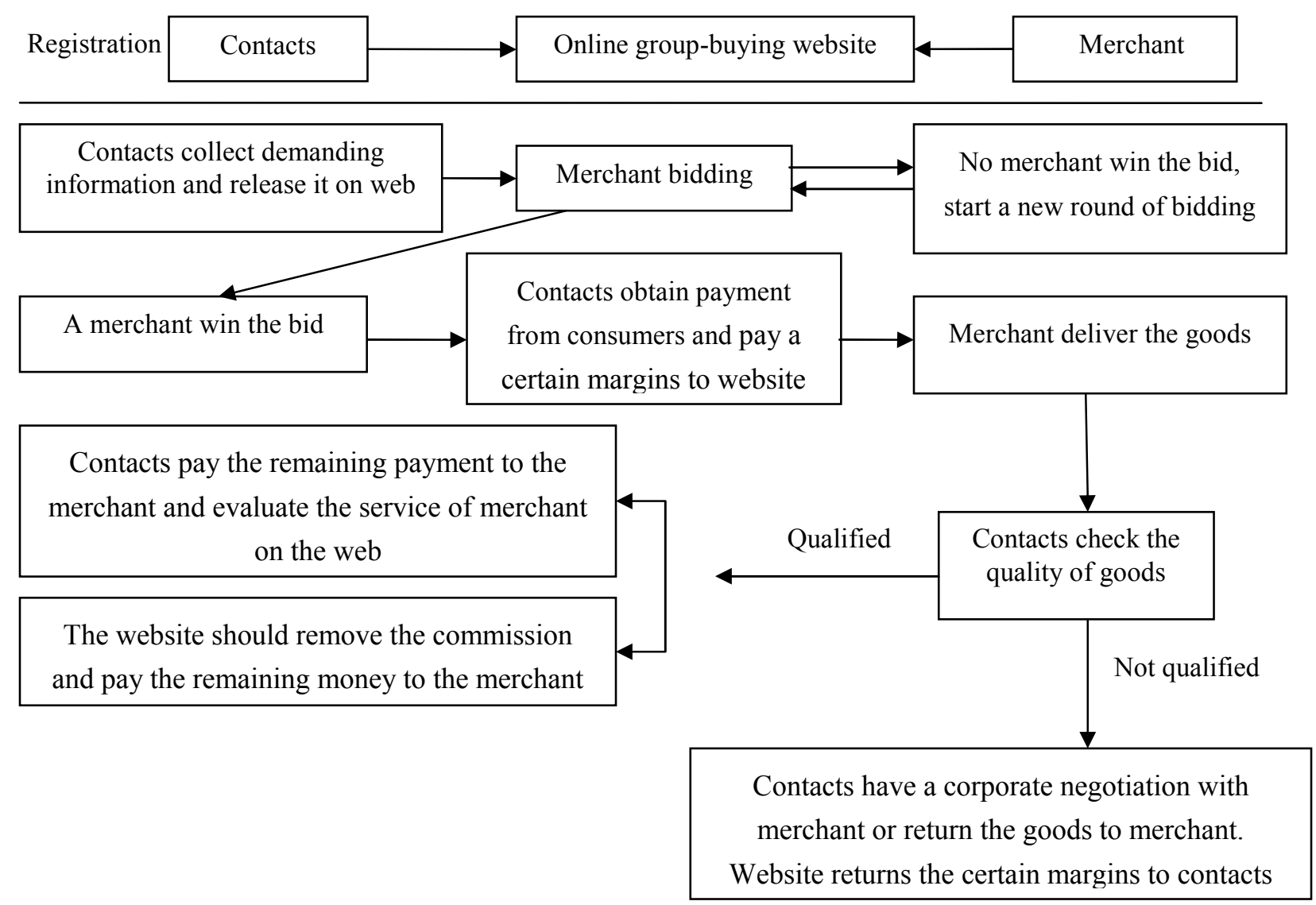

Fig.2 The process of rural online group-buying based on contacts 


\section{Analysis on the SWOT of the rural online group-buying model based on contacts}

\section{Advantages}

(1) Advantages on the cost and price

First, from the views of farmers and merchants, not matter it is the sale of agricultural material or agricultural products, the websites built a platform for direct negotiations between peasant and merchant. It ignores some training parts, so both sides can get the same products with lower prices. Second, a single trading volume of rural group-buying is stronger than that of traditional model. The scope for deals in rural group-buying market is concentrated, while it is scattered in the traditional market. The businessman can not only reduce the logistics cost, but also gain a large scale economic efficiency. Third, farmers can enhance their bargaining power by the buying-group which can also save a lot of time and logistics cost of transportation.

(2) Advantages of penetrating into the market instantly

There is an obvious disadvantage of information asymmetry in the market economy. Farmers, as a vulnerable group, have very little information resources and always accept some information given by other medias passively. So they are always at a disadvantage position in the competitive environment of the market economy. Farmers can change their disadvantageous position in market economy by the group-buying scheme and available network resources, and do not need to accept the price passively. Compared with traditional model, farmers' right can be guaranteed by the protection of contacts and website. Generally speaking, rural network group-buying model based on the contacts can be accepted by farmers and be promoted in the rural areas with the advantage of penetrating the market quickly.

\section{(3) Advantages of merchants' brand promotion}

In terms of the characteristics that the rural consumer is more easily influenced by the conformity and the word-of-mouth, rural online group-buying gives a channel for promoting the business brand. By the way of the online group-buying, merchants can contact with the rural consumers directly and establish credibility in the minds of consumer easily. Business can attract more consumers to buy the goods by its reputation on group-buying website, so as to improve the popularity and reputation of the enterprise and win consumer approval. Therefore, merchant participating in the group-buying activity is a good marketing pattern and a perfect way to promote corporate brand.

\section{Weakness}

(1) Rural group-buying has a rigid request on time

Generally speaking, agricultural production has a rigid limitation of solar term, so the farmers should receive the agricultural materials at a right time. It requires contacts collect the required information of peasants rapidly. Meanwhile, the merchants should act quickly and distribute the goods to farmer as soon as possible. Then the recycle of transaction can be reduced.

(2) Not conducive to after-sales service

Most residences are concentrated in the rural regions. However, there are also some discrete residences. This situation leads to the fact that the service sites are uncertainty and response time is too long. In addition, the development of traffic facilities is imbalance which is unsuitable for the merchants to provide the after-sale service.

(3) Trading volume of rural online group-buying has time-dependent feature

Since the agricultural production has a limitation of time, the demand of agricultural materials also has a limitation of time. Trading volume of rural online group-buying will burst in short-term. It requires the merchants to make the capacity of logistics and services to meet the requirements in short time.

\section{Opportunity}

\section{(1) Rural electronic business has great potential}

The rural areas have a large population base. With the constant growth of disposable income of farmers, rural consumer market potential is tremendous. Currently, the rural electronic commerce is at the initial stage and the competition in this market is not intense. Therefore, online group-buying industry should pay more attention to this potential market and hold the opportunity to develop. If an enterprise which can focus on the rural market will obtain a good opportunity for development. 


\section{(2) Policy support from government}

In recent years, the government pays more attentions to the problem of "Agriculture, Rural areas and Peasantry" and issues a series of policies to narrow the gap between rural and urban areas. The participants of the rural online group-buying can obtain the policy support from the government.

\section{Threaten}

\section{(1) Rural infrastructure of network and logistics has large regional disparities}

In recent years, we have made a great progress in building the logistics facilities and setting up the rural network. However, the regional difference of that is very large. The infrastructures of eastern coastal cities in China are good, while the infrastructures of the central and western regions are poor. The problem of "one-kilometer" should be resolved well, if the rural online group-buying industry want to make a great progress. Therefore, the group-buying industry should first be promoted in the urban and rural linking areas which have good facility conditions.

\begin{tabular}{|c|c|}
\hline S & W \\
Advantages on the cost and price & $\begin{array}{c}\text { Rural group-buying has a rigid request on time } \\
\text { Not conducive to after-sales service }\end{array}$ \\
instantly & $\begin{array}{c}\text { Not } \\
\text { Trading volume of rural online group-buying } \\
\text { has time-dependent feature }\end{array}$ \\
Rural electronic business has great potential merchants' brand promotion & $\mathrm{T}$ \\
policy support from government & $\begin{array}{c}\text { Rural infrastructure of network and logistics } \\
\text { has large regional disparities }\end{array}$ \\
\hline
\end{tabular}

Fig.3 The SWOT analysis of the business model of rural online group buying based on contacts

\section{Conclusion}

There are $26 \%$ of the internet population and $22 \%$ of the time in the rural market. So the rural market is a favorite area as well as the city. In the near future, rural cyber citizen will be the new economic growth points in the development of the internet and the e-business. Base on the research on the feasibility of the rural online group-buying, this paper proposes a new model of rural group-buying based on the contacts which can work as a theoretical basis and practical guidance for promoting online group-buying activities in rural area. Since the network infrastructures of the rural areas are poor and operational capacity of farmers is at a low level, the new model can compensate these disadvantages by adding a new subject "contacts". In this way, the operations of rural group-buying become feasible. Different from the traditional city-oriented industry, consumers in rural group-buying industry (e.g. "peasant") usually have dual roles. They are not only the consumers but also the producers of agricultural products. So how to incorporate the "on line group-buying" into "network transaction" by the internet is the next research topic which we will devote ourselves to.

\section{Author}

Jian-chi Xiang (1971- ): received the Ph.D. degree in management from business school of Central South University, Changsha, China, in 2009. Now, he is a member of Young Core Instructors in Hunan province and works in the Business school of Hunan Normal University as the associate professor and master instructor. His research interests include management information system, E-commerce, customer relationship management. E-mail: jcxiang@sina.com

Wu-yong Ding (1988- ): received the B.S. degree from Economics School of Central South University of Forestry and Technology, Changsha, China, in 2011. Now, he is pursuing for his M.S. degree in the business School of Hunan Normal University. His research interest is enterprise management. E-mail:wadwy0330@live.cn

Foundation item: the Doctor Foundation of Hunan Normal University. No. JI10060 


\section{Reference}

[1] China internet network information center, 29th Statistical Report on Internet Development in China[R]. 2012.01.16. http://www.cnnic.net.cn/dtygg/dtgg/201201/t20120116_23667.html

[2] Anand K. S., Aron R... Group Buying on the Web: A Comparison of Price-Discovery Mechanisms [J]. Management Science, 2003, 49 (11):1546- 1562.

[3] Ling tuan Wang, The national online group buying Census data commnique in 2011[R].http://zixun.lingtuan.com/article- 22230-1.html

[4] National Bureau of Statistics, 2010 Sixth National population census data Gazette (No. 1)" [R]. 2011.4.28. http://www.stats.gov.cn/tjgb/rkpcgb/qgrkpcgb/t20110428_402722232.htm

[5] Ministry of Transport of People's Republic of China ,Statistical bulletin of Highway and Waterway transport sector's development in 2011 (part of rural roads) [R].2012.05http://www.moc.gov.cn/06road/shuju/201205/t20120508_1237014.html

[6] Yonatan Guo, The development achievements and prospects of informatization of Chinese agriculture and villages [J], E-Government. 2012(Z1)

[7] Baochun Zhao, The relationship between consumer's birthplace and the ethical beliefs: the empirical Study under the background of Chinese urban and rural social context [J], Management world.2011 (01) 